Peer-Reviewed Article

ISSN: 2162-3104 Print/ ISSN: 2166-3750 Online

Volume 5, Issue 2 (2015), pp. 161-174

(C) Journal of International Students

http://jistudents.org/

\title{
Expectations and Experiences of Inbound Students: Perspectives from Sweden
}

\author{
Per A Nilsson, MA \\ International Director, Communication and International Relations Office \\ Umeå University (Sweden)
}

\begin{abstract}
This paper explores expectations and outcomes for inbound students at Umeå University, Sweden, comparing their expectations with what they actually experienced. Based on an initial sample of 296 students, 116 answered surveys before and after experiencing of studying abroad. The same individuals have been followed. Most of the respondents' expectations were fulfilled. Hence, the comprehension of what to expect when it comes to 'personal' experiences was shown to be in line with the respondents' expectations. However, the 'academic' experiences seemed to be more difficult to grasp in advance. Some respondents also changed their opinions regarding some of their expectations. The study has followed the same individuals over time and adds new knowledge to the field of student mobility.
\end{abstract}

Key words: Inbound Students, Student Mobility, Experiences and Expectations, Sweden.

Nowadays, a growing number of university students have become 'mobile', with more opportunities than ever before to study abroad. One important reason for this is the increase in courses taught in English in non-English speaking countries. For that very reason, Sweden has seen a large increase in inbound international students in the last decade. The language of instruction is a critical factor for receiving international students. The wide range of courses and programs taught in English makes it easier to recruit international degree students, accept incoming exchange students, and cooperate with international partner universities. Consequently, Sweden has emerged as a new player on the global education market. When Sweden introduced tuition fees for non-European students in 2011, a sharp drop in new enrollments was observed (see Table 1). It is noteworthy that domestic students and students from within Europe are able to study without paying tuition fees. This option is now available to most students, and many will have an international study experience during their studies. Thus, emphasizes Knight (2012), international student mobility has transformed the higher education landscape. Since the 1970s, the number of students studying abroad has increased considerably worldwide. Approximately 
800,000 university students were enrolled in studies outside their country of citizenship in 1975, compared to over four million today (OECD, 2013). Therefore, for many students, international education and student mobility have become an important part of their university experience.

Table 1

Inbound students in Sweden, new enrollments for academic years 2003/04 - 2012/13

\begin{tabular}{|c|c|c|c|c|c|c|c|c|c|c|}
\hline $\begin{array}{l}\text { Academic } \\
\text { Year }\end{array}$ & $03 / 04$ & $04 / 05$ & $05 / 06$ & $06 / 07$ & $07 / 08$ & $08 / 09$ & $09 / 10$ & $10 / 11$ & $11 / 12$ & $12 / 13$ \\
\hline $\begin{array}{l}\text { Exchange } \\
\text { Students }\end{array}$ & 8,800 & 9,600 & 10,100 & 10,900 & 11,800 & 12,700 & 13,800 & 14,600 & 14,800 & 14,700 \\
\hline $\begin{array}{l}\text { Degree } \\
\text { Students }\end{array}$ & 5,700 & 6,700 & 8,100 & 8,200 & 9,800 & 11,600 & 12,900 & 14,700 & 5,900 & 6,900 \\
\hline $\begin{array}{l}\text { Fee-paying } \\
\text { Students }\end{array}$ & & & & & & & & & 1,227 & 1,502 \\
\hline TOTAL $=14,6$ & & 16,300 & 18,200 & 19,100 & 21,600 & 24,2000 & 26,700 & 29,200 & 20,800 & 21,600 \\
\hline
\end{tabular}

Source: The Official Statistics of Sweden (2013). International mobility in higher education from a Swedish perspective 2012/13, UF 20 SM 1302.

Students studying abroad lead to questions about their expectations and how these are met. By choosing to study abroad, students take a significant step in setting in motion their own individual life projects, and it can be assumed that they have dreams and aspirations of having a great experience, be it for academic or personal development. However, little is known regarding whether the students' expectations are fulfilled after studying abroad. Thus, learning more about whether and how expectations are met is crucial both for a deeper understanding of student mobility, and understanding the rationales and drivers behind it. This article deals with international student mobility. Students' expectations are compared with what they actually experienced while studying abroad. They arrive with a set of expectations, and depart with their own experiences of having studied abroad, and all are influenced by their studies, their environment, the cost of living, etc. The aim here is to study the expectations inbound students had when enrolling, and the experience they gained after approximately six months of studying in Sweden. This study, following the same students over a period of time, adds new knowledge to the field of student mobility when it comes to inbound students' expectations and experiences.

\section{Push-Pull models}

\section{Conceptual Framework}

External and internal environment play an important role for mobility and internationalization in general. The interplay of multiple push and pull variables is complex. Some variables have hindered mobility but many more have enabled it to grow for decades worldwide (Choudaha \& de Witt, 2014). The conceptual framework of this study was inspired by 'Push-Pull' models (e.g. Mazzarol \& Soutar, 2001; Li \& Bray, 2007) in order to learn more about students' expectations related to student mobility. We know, based on these models that economic and social forces can push students abroad, and cultural awareness and curiosity about another country can attract or pull them. However, some have observed a reversed push-pull force (Li \& Bray, 2007), positive forces at home and negative forces abroad can also explain why some students stay put or decide to study closer to home. It is obvious that many factors can 
attract students to study abroad. Their expectations depend on, among other things, the length of time spent studying abroad. Therefore, it can be argued that most international students are prompted by a mixture of expectations, including the motives of typical tourists such as the desire to experience something different from everyday life.

The Push-Pull model is used in this study in order to understand the rationales and drivers behind student mobility. Economic and social forces in the students' home countries serve to push them abroad, and they expect work and career opportunities as well as a decent salary. Similarly, cultural experiences, personal development, and linguistic improvements are often major reasons why students choose to study abroad (Maiworm \& Teichler, 1996; Teichler, 2002; Bracht, Engel, Jonson, Over, Schomburg \& Teichler, 2006; Thissen \& Ederveen, 2006). Consequently, the choice of study destination depends on a variety of pull factors such as knowledge and awareness of the host country, personal recommendations, cost issues, the 'environment', geographic proximity, and social links (Mazzarol, Kemp \& Savery, 1997).

\section{Pull motives}

Most studies show that students' expect to experience a new culture and to develop as a person, but that they also expect an international experience to be positive for their career (cf. the Swedish International Program Office for Education and Training 2002; 2008; Centre for International Mobility, the Swedish Council for Higher Education and Norwegian Centre for International Cooperation in Education, 2013). Thus, their expectations include personal expectations, and not just strictly academic ones. However, their expectations also concern the length of the study period abroad. Exchange students are looking for a broader experience from a temporary study period at a foreign university. This includes the learning experience, e.g. with high-quality education, favorable learning environments, high-quality lectures and tutors, etc. although exchange students seem to value the total experience of having studied abroad.

\section{Push motives}

The possibilities of increasing one's chances of getting a job is an important motive, but it seems to be more important to students to have degree mobility; this is one important reason why many will pay tuitions fees to earn a degree from a foreign university (OECD, 2013). Consequently, there are push motives such as migration or increasing employability on one's home labor market. In parts of the world, for instance Asia, Africa, and the Middle East, acquiring an education at a higher education institution is very difficult because of the lack of relevant study opportunities at home (OECD, 2013).

Degree mobility is less rigid and the decision to enroll can quickly change (i.e., be more "spontaneous"), at least in comparison with exchange students participating in an organized activity based on a signed agreement between partner universities, planned months ahead of time. Degree students stay abroad for an entire program of study, for instance to earn a Master's Degree. In conclusion, many studies show that students' motives for studying abroad can be grouped into three main categories related to personal growth, career, and academic aspects (cf. Centre for International Mobility, the Swedish Council for Higher Education and Norwegian Centre for International Cooperation in Education, 2013).

\section{Follow-up Studies}

Outcomes of experiencing studying abroad can be difficult to evaluate depending on when follow-up studies take place. This can range from immediately after a period abroad to several 
years later, but it also depends on whether the studies target exchange students or international students in general. Moreover, the country studied can explain why results from follow-up studies can differ. For example, students in the Nordic countries have good opportunities for financial support when studying abroad which other students around the world lack (Centre for International Mobility, the Swedish Council for Higher Education and Norwegian Centre for International Cooperation in Education, 2013).

\section{Employability and Career}

Some follow-up studies have focused on employability and career, and the question of whether having studied abroad leads to a greater probability of employment after finishing one's degree. Lianos, Asteriou and Agiomirgianakis (2004) conducted a study of Greek graduates of foreign universities who sought employment in Greece. Greece has the highest number of students studying in other EU member states. According to the study, Greeks who graduates from European universities outside Greece are better placed on the Greek labor market from an employability point of view.

Bracht et al. (2006) concluded that former Erasmus students cannot count on higher income or status but are more often employed in international work assignments and are often internationally mobile, compared to their immobile peers. Only former Erasmus students from Central and Eastern European countries can generally count on better career opportunities than their immobile peers, i.e. students from nations joining EU late. A study by Maiworm and Teichler (1996) shows that Erasmus students often find work that allows them to exploit the distinctive skills they gained while studying abroad. Norris and Gillespie (2009) found that studying abroad truly does change one's life, as the respondents' career choices were affected by the experience of studying abroad. In addition, mobile students more frequently have jobs with international work assignments (Wiers-Jenssen, 2013).

\section{Academic Achievements}

Other follow-up studies have focused on academic achievements. From the outset in the early 1990s, academic achievements were on the Erasmus agenda (Teichler, 2004). However, several studies (cf. the Swedish International Program Office for Education and Training, 2002; 2008) indicate that students appreciate the broad spectrum of experiences they have when temporarily studying abroad. Furthermore, some follow-up studies have emphasized the learning experience of temporarily studying in Europe (King and Ruiz-Gelices, 2003). Experiencing a year abroad led to linguistic improvements, the cultural experience of living in another country, and further general personal development. While career prospects improved after studying abroad, academic learning experiences were less significant. These findings are similar to those of many other studies of student mobility (e.g. Maiworm \& Teichler, 1996; Teichler, 2002). Hence, Teichler (2004) emphasizes the experiences the students have of daily life in another European country, including all its elements, as an asset and an important learning experience.

\section{Life Satisfaction}

Some studies focus on life satisfaction and the extent of one's social network (Gomes, Berry, Alzougool \& Chang, 2014). Some studies indicate the extent of loneliness and/or isolation among international students (Sawir, Marginson, Deumert, Nyland \& Ramia, 2008).

The expectations and experiences of studying abroad are multifaceted. What motivates some students to study abroad might be an obstacle for others. For instance, friends and family might 
be a major reason for not studying abroad or an important source of encouragement to actually do so (Centre for International Mobility, the Swedish Council for Higher Education and Norwegian Centre for International Cooperation in Education, 2013).

\section{Research Method}

\section{Participants}

The survey was directed at inbound international students coming to Umeå University, a comprehensive university in northern Sweden with 33,000 students, in the 2008-2009 academic year. Participants were recruited from the group of inbound students enrolling at Umeå University, prior to the beginning of the fall semester. The university had a total of 1,761 international students in the 2008-2009 academic year, and the number of international students enrolled for the 2008 fall semester comprised approximately 425 exchange students and 350 international degree students. When students arrive at Umeå University, they are offered an introduction week, an orientation course, to get started as students. During this orientation, approximately 400 students meet "face-to-face". All the international students attending the orientation week were invited and encouraged to participate in the survey as part of a quality assessment program.

There were 296 responses to the first survey (139 male and 156 female, one missing value), yielding a response rate of $74 \%$. The follow-up survey distributed six months later, was directed at the 296 students who had answered the first questionnaire, received 116 responses, yielding a total response rate of 39\%. Drop-outs in the follow-up survey were mainly the result of students having changed their e-mail address and therefore could not reached. Also, after finishing the fall semester at Umeå University, some of the exchange students returned to their home institution to continue their studies, and perhaps lost interest in answering the second survey. Thus, of the initial sample of 296 students, 116 answered both surveys, and data from these respondents are used in this article. An analysis of the drop-outs between the first and second data collection indicates no bias with respect to gender, age or study program (see Table 2). Therefore the data set constitutes a panel.

\section{Research Procedure}

The first survey was carried out as a hand-out paper survey in August 2008, prior to the fall semester. The follow-up survey was a web-based questionnaire issued during the 2009 spring semester (March). The students answered questions about their previous experiences of travelling and living abroad, their motives for enrolling in an international study program, their choice of study destination, and their expectations (such as learning Swedish, courses taught in English, experiencing winter, attractive courses, reputation of the university, standard of accommodation). The questions covered the students' perception of Sweden, difficulties getting to know Swedes and making friends, and the attraction of an informal lifestyle. In the first survey, when the students had just arrived, the scale 'not important' to 'very important' was used for the components; 'Sweden is an expensive country', 'Experience winter', 'The informal lifestyle in Sweden', 'Difficult to make friends', 'The reputation of Umeå University', 'Attractive courses at Umeå University', 'Many courses taught in English', and 'High standard of accommodation'. 


\section{Table 2}

A comparison between the first survey and the panel (i.e. answering both surveys)

\begin{tabular}{lll}
\hline & First survey $\mathrm{n}=296$ & Panel $\mathrm{n}=116$ \\
\hline $\begin{array}{l}\text { Gender } \\
\text { Female }\end{array}$ & $156(53 \%)$ & $57(49 \%)$ \\
Male & $139(47 \%)$ & $59(51 \%)$ \\
Mean age & $23.3 \pm 2.8$ & $24.5 \pm 2.8$ \\
Citizenship & & \\
EU/EEA & $196(66 \%)$ & $85(73 \%)$ \\
$\quad$ Non-EU/EEA & $95(32 \%)$ & $29(25 \%)$ \\
Missing & $5(2 \%)$ & $3(2 \%)$ \\
Field of studies & & \\
$\quad$ Humanities & $17(6 \%)$ & $12(10 \%)$ \\
$\quad$ Social Sciences (incl. Law \& Business) & $162(55 \%)$ & $52(45 \%)$ \\
$\quad$ Teacher Training & $12(4 \%)$ & $6(5 \%)$ \\
$\quad$ Natural Sciences and Technology & $59(20 \%)$ & $25(22 \%)$ \\
Medicine and Odontology & $22(7 \%)$ & $12(10 \%)$ \\
Healthcare & $9(3 \%)$ & $4(3 \%)$ \\
Arts and Fine Arts & $2(1 \%)$ & 0 \\
$\quad$ Missing & $13(4 \%$ & $6(5 \%)$ \\
Length of studies & & \\
Exchange students (1 or 2 semesters) & & $95(82 \%)$ \\
Degree students (3 or more semesters) & $244(83 \%)$ & $21(18 \%)$ \\
\hline
\end{tabular}

All statistical analysis was performed using SPSS, version 17.0 for Windows. A statistical data evaluation was performed using non-parametric tests, as some of the samples were not normally distributed. The Wilcoxon signed ranked test was used to study paired observations, (e.g. to compare the respondents answers after studying for more than six months with their answers they gave when they had just arrived in Sweden). The Mann-Whitney test was used to compare differences between groups. The level of statistical significance was set to $\mathrm{P}<0.05$. A principal component analysis (PCA) was also performed. Scree tests were used to determine the number of components to be included. These components also had eigenvalues $>$ 1. Direct oblimin rotation was used.

\section{Results}

The panel (i.e. respondents answering both surveys) shows that the students came from 35 different countries and that approximately $70 \%$ of them were citizens of a European country. Most came from Germany $(n=40)$ and France $(n=13)$. There was a total of 95 exchange students. Their mean age was 24.5; 59 were men and 57 women. One fourth had visited Sweden before, and $9 \%$ had family or friends in Umeå. Most of the students had no, or very limited, knowledge, of the Swedish language. However, 97\% of them expressed that they wanted to learn Swedish. Less than half of the respondents studied Social Sciences (including Law and Business), 22\% 
studied Natural Sciences and Technology and the rest studied Humanities, Fine Arts, Teacher Education, Healthcare, Odontology and Medicine.

The respondents were experienced travelers, and seemed to be internationally experienced, having visited a large part of the world before coming to Sweden. Most of them had previously studied, traveled and/or worked in a foreign country. They had previously visited Europe (80\%), the Nordic countries (38\%), North America (33\%), Asia (23\%), Africa (18\%), South America (11\%), the Middle East (7\%), and Oceania (7\%).

Table 3

How can your expectations best be described?

\begin{tabular}{lcc}
\hline & Frequency & Percentage (\%) \\
\hline It's going to be an adventure & 24 & 20.7 \\
It's going to be nice to change study environment & 24 & 20.7 \\
I'll be able to study in a more stimulating academic & 17 & 14.7 \\
milieu & & \\
It will be interesting to learn about another culture & 14 & 12.1 \\
Studying abroad will make it easier to get a job & 7 & 6.0 \\
I can learn another language & 7 & 6.0 \\
It's going to be nice to live in another climate & 3 & 2.6 \\
Other matters & 4 & 3.4 \\
Missing & 16 & 13.8 \\
TOTAL & 116 & 100 \\
\hline
\end{tabular}

When asked about their expectations, respondents answered that their decision to study abroad was more about their personal than their strictly academic expectations. Important personal statements were that they wished to experience an 'adventure' or a 'change of study environment', and that it would be 'interesting to meet another culture'. Moreover, studying in a more 'stimulating academic milieu' was important. In addition, when the respondents answered a single question about why they had chosen Umeå University, 57\% cited the university as a study destination and $41 \%$ cited the northern Sweden location of the city of Umeå. What did the respondents actually experience at Umeå University after more than six months of studies (see Table 4)? Students have expectations before enrolling at a foreign university; in the respondents' reports of their 'personal' experiences, their pre-assumptions were different from how they had experienced it to be. Notable is their expectation that the cost of living would be similar to that at home. Their expectation of winter and the informal lifestyle in Sweden were lower than their actual experiences proved to be, and they enjoyed these aspects more than they had expected to. The respondents also reported that it had been easier than expected to make friends, and that they had positive associations regarding working and living outside their home country. The respondents had high expectations when it came to developing as a human being and, in their actual experiences; this had been more than fulfilled.

Regarding academic expectations, the respondents experienced that the university had a better reputation than expected, and that the courses were also more preferable than they had expected. Furthermore, the number of courses taught in English was a positive experience. However, the respondents did not develop their language skills as much as they would have 
liked. They also found the quality of courses was not better than at home. In addition, the respondents found that the standard of accommodation was better than they had expected.

\section{Table 4}

A comparison: what did the respondents experience after more than six months of studies in a foreign country?

\begin{tabular}{llllll}
\hline & $\begin{array}{l}\text { Before } \\
\mathrm{n}=116\end{array}$ & $\%$ & $\begin{array}{l}\text { After } \\
\mathrm{n}=116\end{array}$ & $\%$ & $\mathrm{p}$ value \\
\hline \multicolumn{1}{c}{ Academic experiences } & & & & & \\
Develop language skills & 105 & 90.5 & 98 & 84.5 & 0.035 \\
High standard of accommodation & 60 & 51.7 & 98 & 84.5 & 0.190 \\
Attractive courses at Umeå University & 81 & 69.8 & 86 & 74.1 & 0.050 \\
The reputation of Umeå University & 72 & 62.1 & 84 & 72.4 & 0.014 \\
Many courses taught in English & 50 & 43.1 & 55 & 47.4 & 0.017 \\
The quality of courses higher than at home & 70 & 60.3 & 51 & 43.9 & $<0.0001$ \\
$\quad$ Personal experiences & & & & & \\
Develop as a human being & 104 & 89.6 & 110 & 94.8 & $<0.0001$ \\
Change and new experiences & 111 & 95.7 & 110 & 94.8 & 0.237 \\
Experience winter & 70 & 60.3 & 94 & 81.0 & $<0.0001$ \\
The informal lifestyle in Sweden & 77 & 66.4 & 87 & 75.0 & 0.070 \\
Work outside my home country & 73 & 62.9 & 82 & 70.7 & $<0.0001$ \\
Difficult to make friends & 99 & 85.3 & 77 & 66.4 & 0.571 \\
Expensive country & 44 & 37.9 & 94 & 81.0 & 0.013 \\
\hline
\end{tabular}

Note: A Likert scale was used in the survey, and results 5, 6, and 7 on the scale are shown in the table.

Factors that are of significance to inbound students are identified in the crossover matrices (Tables 5 and 6). Inbound students have many and varied expectations when it comes to studying abroad. According to this study, most of the respondents' expectations were fulfilled, but did they change their opinions after six months of studies abroad? In Table 5, respondents' personal experiences are compared with their expectations in a crossover matrix. On a general level, the pattern is quite stable. The vast majority of the respondents who had positive expectations were still positive after experiencing studying abroad, especially concerning personal development, reflected in aspects like 'develop as a human being' and 'change and new experiences'. However, one can also note that some changed their views during their stay, especially regarding aspects such as 'winter', 'informal lifestyle' and 'working internationally'. However, the high cost of living seems to have surprised the respondents; approximately $46 \%$ changed their views on this aspect. Furthermore, making friends proved to be easier than expected. A quarter of the respondents changed their views after experiencing studying abroad. Thus, for these two components, one can see a shift in stance before and after studying abroad. Moreover, many respondents changed from a negative to a positive stance on aspects such as the university's reputation (22\%), and accommodation (38\%). Similarly, when it came to the quality of the courses, the respondents had expected it to be 'higher than at home'; approximately $27 \%$ changed their views on this from positive to negative. 
Table 5

Crossovers - respondents' personal expectations in advance compared with their experiences after a period of studying abroad.

\begin{tabular}{|c|c|c|}
\hline Sweden an expensive country & Frequency & Percent \\
\hline The expectation $(+)$ and the experience $(+)$ & 41 & 35.3 \\
\hline The expectation (-) and the experience (+) & 53 & 45.7 \\
\hline The expectation (-) and the experience (-) & 19 & 16.4 \\
\hline The expectation (+) and the experience (-) & 3 & 2.6 \\
\hline TOTAL & 116 & 100 \\
\hline Experience winter & Frequency & Percent \\
\hline The expectation $(+)$ and the experience $(+)$ & 67 & 57.8 \\
\hline The expectation (-) and the experience (+) & 27 & 23.3 \\
\hline The expectation (-) and the experience (-) & 19 & 16.4 \\
\hline The expectation (+) and the experience (-) & 3 & 2.6 \\
\hline TOTAL & 116 & 100 \\
\hline The informal lifestyle in Sweden & Frequency & Percent \\
\hline The expectation $(+)$ and the experience $(+)$ & 62 & 53.4 \\
\hline The expectation (-) and the experience $(+)$ & 25 & 21.6 \\
\hline The expectation (-) and the experience (-) & 14 & 12.1 \\
\hline The expectation (+) and the experience (-) & 15 & 12.9 \\
\hline TOTAL & 116 & 100 \\
\hline Work outside my home country & Frequency & Percent \\
\hline The expectation (+) and the experience $(+)$ & 64 & 55.2 \\
\hline The expectation (-) and the experience (+) & 18 & 15.5 \\
\hline The expectation (-) and the experience (-) & 25 & 21.6 \\
\hline The expectation (+) and the experience (-) & 9 & 7.8 \\
\hline TOTAL & 116 & 100 \\
\hline Develop as a human being & Frequency & Percent \\
\hline The expectation $(+)$ and the experience $(+)$ & 104 & 89.7 \\
\hline The expectation (-) and the experience (+) & 6 & 5.2 \\
\hline The expectation (-) and the experience (-) & 6 & 5.2 \\
\hline The expectation (+) and the experience (-) & 0 & 0 \\
\hline TOTAL & 116 & 100 \\
\hline Change and new experience & Frequency & Percent \\
\hline The expectation $(+)$ and the experience $(+)$ & 107 & 92.2 \\
\hline The expectation (-) and the experience $(+)$ & 3 & 2.6 \\
\hline The expectation (-) and the experience (-) & 2 & 1.7 \\
\hline The expectation (+) and the experience (-) & 4 & 3.4 \\
\hline TOTAL & 116 & 100 \\
\hline Difficult to make friends & Frequency & Percent \\
\hline The expectation $(+)$ and the experience $(+)$ & 72 & 62.1 \\
\hline The expectation (-) and the experience (+) & 5 & 4.3 \\
\hline The expectation (-) and the experience (-) & 12 & 10.3 \\
\hline The expectation (+) and the experience (-) & 27 & 23.3 \\
\hline TOTAL & 116 & 100 \\
\hline
\end{tabular}


Table 6

Crossovers - respondents' academic expectations in advance compared with their experiences after studying abroad.

\begin{tabular}{|c|c|c|}
\hline The reputation of Umeå University & Frequency & Percent \\
\hline The expectation (+) and the experience $(+)$ & 59 & 50.9 \\
\hline The expectation (-) and the experience (+) & 25 & 21.6 \\
\hline The expectation (-) and the experience (-) & 17 & 14.7 \\
\hline The expectation (+) and the experience (-) & 13 & 11.2 \\
\hline Missing value & 2 & 1.7 \\
\hline TOTAL & 116 & 100 \\
\hline Attractive courses at Umeå University & Frequency & Percent \\
\hline The expectation (+) and the experience (+) & 67 & 57.8 \\
\hline The expectation (-) and the experience (+) & 17 & 14.7 \\
\hline The expectation (-) and the experience (-) & 15 & 12.9 \\
\hline The expectation (+) and the experience (-) & 18 & 15.5 \\
\hline TOTAL & 116 & 100 \\
\hline Many courses taught in English & Frequency & Percent \\
\hline The expectation $(+)$ and the experience $(+)$ & 34 & 29.3 \\
\hline The expectation (-) and the experience (+) & 21 & 18.1 \\
\hline The expectation (-) and the experience (-) & 45 & 38.8 \\
\hline The expectation $(+)$ and the experience (-) & 16 & 13.8 \\
\hline TOTAL & 116 & 100 \\
\hline Develop language skills & Frequency & Percent \\
\hline The expectation $(+)$ and the experience $(+)$ & 95 & 81.9 \\
\hline The expectation (-) and the experience (+) & 3 & 2.6 \\
\hline The expectation (-) and the experience (-) & 4 & 3.4 \\
\hline The expectation $(+)$ and the experience $(-)$ & 14 & 12.1 \\
\hline TOTAL & 116 & 100 \\
\hline High standard of accommodation & Frequency & Percent \\
\hline The expectation $(+)$ and the experience $(+)$ & 54 & 46.6 \\
\hline The expectation (-) and the experience (+) & 42 & 36.2 \\
\hline The expectation (-) and the experience (-) & 11 & 9.5 \\
\hline The expectation $(+)$ and the experience (-) & 9 & 7.8 \\
\hline TOTAL & 116 & 100 \\
\hline The quality of courses higher than at home & Frequency & Percent \\
\hline The expectation $(+)$ and the experience $(+)$ & 42 & 36.2 \\
\hline The expectation (-) and the experience (+) & 9 & 7.8 \\
\hline The expectation (-) and the experience (-) & 34 & 29.3 \\
\hline The expectation $(+)$ and the experience (-) & 31 & 26.7 \\
\hline TOTAL & 116 & 100 \\
\hline
\end{tabular}

Additionally, in Table 6, respondents' academic experiences are compared with their expectations in a crossover matrix. Here the pattern is less stable than for personal experiences. 


\section{Principal component analysis (PCA)}

A principal components analysis (PCA) was done for a more rigorous analysis of the determinantes. The PCA identified five significant components (eigenvalues 2.65, 1.56, 1.47, 1.20, and 1.06). The full model explained $61.2 \%$ of the variance. The first component captured the largest variation in the material and explained $20.4 \%$ of the variance. The other four components together explained $40.8 \%$ of the variance. The aspects that highly contributed to component one were: the reputation of Umeå University, the standard of accommodation, the informal lifestyle in Sweden, and developing language skills. In components two and four, language skills contributed highly together with the quality of courses being better than at home. In component three, the aspects change and new experiences and developing as a human being contributed highly. In component five, the many courses taught in English contributed highly.

\section{Main Findings and Discussion}

The Umeå University case is a limited study and was chosen because of good collaboration with its international office. Furthermore, the study relied on a relatively small group of inbound students. Also, the students were followed up after a comparatively short period of time. Moreover, the self-constructed questionnaire about the students' expectations, previous experience of travelling etc., was not validated, which is also a weakness. Additionally, the case is from a university in Northern Europe, Scandinavia. These limitations will of course make any conclusions drawn from the study tentative.

This study has followed the same individuals over time in order to learn more about whether and how their expectations were met. The respondents' experiences were somewhat different from their expectations, but when it comes to aspects like 'personal development' and 'develop as a human being', their expectations were fulfilled. It should be emphasized that the experience of studying abroad made the respondents more determined to work internationally; about $55 \%$ of them were positive before experiencing studying abroad and they stayed positive. Approximately $16 \%$ changed their stance from negative to positive. Thus, the respondents had a positive outlook on working outside their home country.

This study has shown that a period abroad change the respondents' perspectives and, for some of them, the long-term impact could be a career in an international business or organizations; this is a missed opportunity for those who do not participate in experiencing a period of studying abroad. The main results from the study indicate that the respondents' expectations were in accordance with what they actually experienced. However, they changed their opinions on many of aspects after having personally experienced studying abroad. Thus, experiencing a period of studying abroad includes many aspects, some of which are difficult to foresee. The increase in the number of courses taught in English in non-English speaking countries has given students worldwide more options to study abroad. This development has made many universities more attractive, and the wide range of courses and programs taught in English has made it easier to recruit international students. The emergence of new players on the international education market has been beneficial to countries like Sweden. However, for students, tuition fees, and the costs of living in a foreign country are of the utmost importance. The fact that Sweden introduced tuition fees for non-European students in 2011 emphasizes the importance of meeting students' expectations in order not to harm the reputation of the study destination. The reputation of an institution or particular program is very important, as are relaxed immigration policies, for encouraging international students to enter the labor market 
after finishing their degree. Hence, to pull students to a study destination, a university needs to be perceived as attractive.

The rationales and drivers for student mobility can be mirrored by Push-Pull models, but in order to expect something you first need knowledge about what to expect. Inbound students seem to have a strong pull reason for studying abroad, although the students in this study misjudged some of the challenges of student mobility. This study shows they were reasonably able to predict aspects of their lives such as personal development in a foreign country. Among the aspects that surprised them was the cost of living, which is easy to learn about in advance.

This study confirms that academic learning is not generally superior to other experiences (Thissen \& Ederveen, 2006; Teichler, 2012). However, the attractiveness of the courses and the reputation of the university are important. The findings in this study indicate that a period of studying abroad enriches students' lives, but they also confirm that a fraction of students study abroad; students who are internationally experienced. It is clear that these students see studying abroad not only as an opportunity but also as a way to use the experience as a merit later in life.

It seems as if the international students were looking for a cultural rather than academic experience. However, some studies have shown that academic and cultural learning during a study period are closely intertwined (Teichler, 2012). It is surprising to note that current students do not have an accurate understanding of what they can expect, considering that many have a global lifestyle and good knowledge of what is happening in the world. Could it be that students simply become mobile rather than choosing to be (Carlson, 2012)?

\section{Conclusion}

This study has focused on student mobility, following the same individuals over time, and it has added new knowledge to the field of student mobility when it comes to inbound students' expectations and what they actually experience. However, student mobility is changing. Academic mobility started with people to people and then developed to mobility within specific programs. According to Knight (2014), the next step will be international education hubs. Similarly, cross-border education was first about cooperation between universities and has now developed into a commercially driven framework. What kind of impact will this have on student mobility in the future?

In Europe, approximately 200,000 students participate annually in the Erasmus mobility program. For them, as found by Teichler (2004), learning to perceive and appreciate diversity will probably continue to be an important part of the experience of being exchange students studying abroad. Furthermore, how universities communicate with potential international students needs to be improved, and the academic and personal achievements that are possible when studying abroad need to be emphasized. If students are better prepared, their expectations will be more in aligned with their experiences. In other words, to have accurate expectations for studying abroad one needs to be well informed. Consequently, the marketing and communication of courses and programs should focus on aspects such as personal development and the establishment of new relationships when studying abroad.

\section{REFERENCES}

Bracht, O., Engel, C., Janson, K., Over, A., Schomburg, H., \& Teichler, U. (2006). The 
Professional Value of ERASMUS Mobility. Final report of the VALERA project. International Centre for Higher Education Research (INCHER-Kassel), University of Kassel, Kassel, Germany.

Centre for International Mobility (CIMO), the Swedish Council for Higher Education and Norwegian Centre for International Cooperation in Education (SIU). (2013). Living and learning - exchange studies abroad. A study of motives, barriers and experiences of Finnish, Norwegian and Swedish students. Retrieved from: http://utbyten.se/sv/Container/Uppmuntran-viktig-for-beslut-om-utbytesstudier/

Choudaha, R., \& De Wit, H. (2014). Challenges and Opportunities for Global Student Mobility in the Future: a comparative and critical analysis, in B. Streitwieser (Eds) Internationalisation of Higher Education and Global Mobility, pp 19-33. Oxford Studies in Comparative Education: Symposium books.

Gomes, C., Berry, M., Alzougool, B., \& Chang, S. (2014). Home away from home: international students and their identity-based social networks in Australia. Journal of International Students, 4 (1), 2-15.

King, R., \& Ruiz-Gelices, E. (2003). International student migration and the European 'Year Abroad': effects on European identity and subsequent migration behaviour. International Journal of Population Geography, 9(3), 229-252.

Knight, J. (2012). Student mobility and internationalization: trends and tribulations. Research in Comparative and International Education, 7(1), 20-33.

Knight, J. (2014). Three Generations of Crossborder Higher Education: new developments, issues and challenges, in B. Streitwieser (Eds) Internationalisation of Higher Education and Global Mobility, pp 43-58. Oxford Studies in Comparative Education: Symposium books.

Li, M. \& Bray, M. (2007). Cross-border flows of students for higher education: Push-pull factors and motivations of mainland Chinese students in Hong Kong and Macau. Higher education, 53(6), 791-818.

Lianos, T.P., Asteriou, D., \& Agiomirgianakis, G.M. (2004). Foreign university graduates in the Greek labour market: employment, salaries and over education. International Journal of Finance and Economics, 9(2), 151-164.

Maiworm, F., \& Teichler, U. (1996). Study abroad and early career. London and Bristol, Kingsley.

Mazzarol, T., Kemp, S., \& Savery, L. (1997). International students who choose not to study in Australia. An examination of Taiwan and Indonesia. Canberra, Australian International ducation Foundation.

Mazzarol, T., \& Soutar, G. (2001). The 'push-pull' factors influencing international student selection of education destination. International Journal of Education Management, 16(2), 82-90.

Norris, E.M., \& Gillespie, J. (2009). How study abroad shapes global careers: evidence from the United States. Journal of Studies in International Education, 13(3), 382-397.

OECD. (2013), Education at a Glance 2013: OECD Indicators. OECD Publishing. Retrieved from: http://www.oecd-ilibrary.org/education/education-at-a-glance2013_eag-2013-en

Sawir, E., Marginson, S., Deumert, A., Nyland, C. \& Ramia, G. (2008) Loneliness and international students: An Australian Study. Journal of Studies in International Education, 12(2), 148-180.

Souto-Otero, M., Huisman, J., Beerkens, M., de Wit, H., \& Vujić, S. (2013). Barriers to 
international student mobility: evidence from the Erasmus program. Educational Research, 41(2), 70-77.

Teichler, U. (2002). Erasmus in the Socrates programme. Findings of an evaluation study. Bonn, Lemmens.

Teichler, U. (2004). Temporary study abroad: the life of Erasmus students, European Journal of Education, 39(4), 395-408.

Teichler, U. (2012). International student mobility and the Bologna process. Research in Comparative and International Education, 7(1), 34-42.

The Official Statistics of Sweden. (2013). International mobility in higher education from a Swedish perspective 2012/13, UF 20 SM 1302. Retrieved from: http://www.ukambetet.se/download/18.575a959a141925e81d11e47/Internationell-studentmobilitet-SM1302.pdf

The Swedish International Program Office for Education and Training, (2002). Sveriges deltagande $i$ Erasmus (Participation of Swedish students in the Erasmus program), 7, Stockholm.

The Swedish International Program Office for Education and Training, (2008). A study conducted by Sifo Research International, working paper. Stockholm.

Thissen, L., \& Ederveen, S. (2006). Higher education: Time for coordination on a European level? Discussion paper, No 68 (CPB Netherlands Bureau for Economic Policy Analysis).

Wiers-Jenssen, J. (2013). Degree mobility from the Nordic countries: Background and employability. Journal of Studies in International Education, 17(4), 471-491.

\section{About the Author}

PER A. NILSSON is working as the International Director at Umeå University in Sweden. In 1982, I received a Bachelor of Science from Umeå University. In 1983, I was rewarded a Master of Arts from University of Minnesota. In 2011, I participated in an international monitoring committee for internationalization at Seinäjoki University of Applied Sciences, Finland.

E-mail: per.nilsson@adm.umu.se 